\title{
Going it Alone or Working as Part of a Team: The Impact of Human Capital on Entrepreneurial Decision Making
}

\begin{abstract}
This paper endeavours to measure the effect that human capital has on the decision taken by the entrepreneur to pursue new venture creation either in a lone capacity or collaboratively. This study applies a logit model to investigate the research relationships. The results show that three factors (experience, social perception and extrinsic motivation) are relevant in the decision to initiate a new venture either in a lone capacity or as part of a collaborative undertaking. The results indicate that previous experience holds the greatest significance on the decision taken by entrepreneurs to ' $\mathrm{go}$ it alone', with factors relating to social perception and extrinsic motivation chiefly predicting a decision to work collaboratively. The findings of this study provide new insight and evidence with regard to the factors that influence a key decision in the start-up process: that of continuing in a lone capacity, or proceeding as part of an entrepreneurial team.
\end{abstract}

Keywords: Human Capital; Entrepreneurial Team; Entrepreneurial Decision; Lone Entrepreneurship

Corresponding author: e-mail: ehormiga@ub.edu

Received 04 January 2017 - Accepted 30 January 2017

This is an Open Access article distributed under the terms of the Creative Commons Attribution-Non-Commercial-No Derivatives License (http://creativecommons.org/licenses/by-nc-nd/4.0/), which permits non-comercial re-use and distribution, provided the original work is properly cited, and is not altered or transformed in any way. 


\section{Introduction}

Significant numbers of studies into entrepreneurial endeavour over the years have considered the entrepreneur as an individual, acting in a lone capacity (Lechler 2001). However, recent research reflects an increasing interest in collaboration between an entrepreneurial team. An increasing number of entrepreneurs decide to undertake business activities as part of a team and to pursue complementarity in order to support and balance the risk and undertaking of new business. Thus, an entrepreneurial team is defined as the group of people involved in the creation and management of a new venture (Forbes et al. 2006).

Several studies have suggested that firms founded and managed by teams are on average more successful than firms founded and managed by individuals (Lechler 2001; Vyakarnam and Handelberg 2005; Kamm et al. 1990; Roure and Maidique 1986). Forming a new company as a group serves to decrease the level of uncertainty, spread responsibility, minimise risk and more effectively leverage support. In this context, literature on entrepreneurship has confirmed the importance of the collaborative entrepreneurship phenomenon (Ribeiro-Soriano and Urbano 2009).

Despite the benefits that working as part of a team brings (Zhou et al. 2015), many entrepreneurs prefer to create a business through their own auspices and in the literature related to this field there is a lack of discussion about why or which factors influence an individual to start a project alone or work as part of an entrepreneurial team. A decision to pursue entrepreneurial endeavour in a lone capacity does not indicate an inability to work as, or contribute to a team, simply that the decision to retain control of company strategy and operations rather than share ownerships and control. Thus, we ask, which factors influence the decision making process? 
This paper will consider the impact that human capital has on the different choices made by entrepreneurs towards initiating a new venture; lone venture or group endeavour. To achieve this objective, the empirical analysis carried out consisted of a logit regression model, with the entrepreneur's decision as dependent variable. Following this introduction, the article is structured in four sections. The first section sets out the theoretical framework that will be utilised to analyse approaches towards the formation of an entrepreneurial team and the influence of the entrepreneur's human capital in the decision making process. The methodology of the work is addressed in section three. Section four includes a demonstration and discussion of the results obtained with logit regression models. Finally, the main conclusions, future lines of research and implications are presented.

\section{Theoretical framework}

The decision to belong to a group: An application to an entrepreneurial team

Groups are formed in an effort to secure particular outcomes and objectives (Cartwright and Zander 1968; Burn 2004; Ben-Hafaiedh-Dridi 2010). In so forming, a decision has been taken that a group will more effectively and efficiently secure the targeted outcomes than an individual working alone would. Or indeed a judgement had been made that particular objectives may not be obtained without working in collaboration (Huici et al. 2011).

Entrepreneurial teams are more common than academic literature has historically suggested (Lechler 2001; Chowdhury 2005). This increase in interest can be attributed to the growth in collaborative start-up ventures. In the last two decades, a change of focus has resulted in less attention in respect of the competencies of the individual entrepreneur and more emphasis on the diversity of competencies demonstrated by the entrepreneurial team (Watson et al. 1995; Frances and Sandberg 2000; Lechler 2001; Ensley et al. 2002; Higashide and Birley, 2002). 
A number of definitions relating to precisely what is meant when referring to an 'entrepreneurial team' can be found in the literature. To this end, Watson et al. (1995) posit that in an entrepreneurial team individuals jointly initiate a business and are involved in its joint operation. An entrepreneurial team has too been characterized as two or more individuals with financial interest jointly launching, actively participating and developing a business (Kamm et al. 1990; Watson et al. 1995; Cooney 2005; Chowdhury 2005).

The reasons behind the decision to pursue an entrepreneurial career with other people instead of 'going it alone' can be very broad. The rational process model of team formation is based on economic and pragmatic instrumental criteria that makes the selection a new member as an issue of complementary skills or assets. In fact the main purpose of a team should be to meet the needs and to obtain the lack of resources (Ucbasaran et al. 2003). Based on this perspective, the decisions are taken with regard to the needs of the project and more specifically to the provenance of those resources (Kamm and Nurick 1993).

In an entrepreneurial team, it is important that the entrepreneur is aware of both identify resource capacity and resource need towards project feasibility. The decision making process focuses on the identification of prospective team member(s) offering the best supply of critical resources to the project (Forbes et al. 2006). During the 'start-up' phase of a business, it is common that founders may not have direct access to the required resources. The rational process model would suggest that the expectation is that resources will be secured from team members or alternatively, from networks (Aldrich and Kim 2007).

From a financial point of view, individuals have an increased likelihood of securing initial funding if they have a partner. In the first instance a partner brings additional initial capital of their own towards the star-up entrepreneurial activity. This initial contribution can be 
monetary or alternatively it may take the form of an unpaid worker salary in the first months. Moreover, entrepreneurial teams are more likely to attract capital investment (Timmons 1999). Usually, the complementary knowledge and competences are perceived as a symbol of team strength and capacity to overcome the inevitable trials and tribulations related to new ventures. Some financiers or even shareholders require a proactive team to support the management of the firm in return for their financial backing (Tihula et al. 2009).

On the other hand, the potential entrepreneur may choose to seek specific competencies, knowledge or skills that s/he does not have; technical, human or conceptual skills (Hambrick et al. 1996). Assertions that teams that are made up of members possessing different skillsets or complementary aptitudes, can positively influence the success of the team performance and, as a consequence, achieve more effective results in respect of the new venture (Roure and Maidique 1986; Utterback et al. 1988; Eisenhart and Schoonhoven 1990; Roberts 1991; Friar and Meyer 2003; Vanaelst et al. 2006). Thus, the variety of experience and knowledge that resides within a team can enrich the decision-making process and provide alternative perspectives. All of which would not be possible if team members possessed the same or similar profiles. Roberts (1991) suggests that one of the key factors for business success is the formation of an entrepreneurial team where different, complementary skills are represented thereby adding value to the new venture.

In the early years of the business, the lone entrepreneur must positively respond and tackle the requirement for very different and varied resources. Thus, a variety of experience, knowledge and expertise among team members provides a synergic effect, which can be applied to the increasingly complex problems of firms (Eisenhart and Schoonhoven 1990). 
Human capital in new ventures: A possible negative effect on team formation propensity While most previous studies have examined team composition, process and effectiveness (Schjoedt and Kraus 2009; West 2007; Vanaelst et al. 2006; Forbes et al. 2006; Molleman and Slomp 2006; Vyakarnam and Handelberg 2005; Rafferty and Tapsell 2001) they do not focus on the reasons that influence an entrepreneur to enrol in group activity as opposed to starting a company as an individual. It remains that a significant proportion of entrepreneurs take the decision to initiate a new venture by 'going it alone'. Based on the rational process model the reasons involved in taking this decision are related to arriving at the conclusion that the skills and complementarity of another are not required to achieve the desired objective. An explanation relating to why potential entrepreneurs in general decide to form a group has been posited, but what factors influence a potential entrepreneur to 'go it alone' or in a group? Wood and Bandura (1989) argue that perceived self-efficacy refers to people's beliefs in their abilities to mobilize the motivation, cognitive resources, and courses of action needed to exercise control over events in their lives. In the context on entrepreneurial activity, entrepreneurial self-efficacy refers to the strength of an individual's belief that he or she is capable of successfully performing the roles and tasks of an entrepreneur (Boyd and Vozikis 1994; Scherer et al. 1989). Self-efficacy and perceived feasibility have all been measured by responding to the question: How confident are you that you can perform the task? (Segal et al. 2005). To this end, if the entrepreneur is confident that they can perform in a lone capacity and therefore the requirement and reliance upon others in an unnecessary inconvenience and therefore negates the need to work with others in a team approach. A crucial aspect of this 
involves the reflection of which characteristics/factors influence a superior feeling of selfefficacy.

Human capital is consistently recognised as being an organisation's most significant, intangible resource (Johanson 2005; Marr and Roos 2005) by playing a fundamental role in the new knowledge-based economy (Becker et al. 2001; Edvinsson and Malone 1997; Sveiby 2000). The technological advances experienced both by firms and society in general have meant that the required worker profile is increasingly one with competencies, attitudes and intellectual agility that permit critical and systematic thinking within the changing and uncertain environment that he/she must confront (Bontis 2002). Therefore, human capital is considered the potential source of innovation and generation of ideas for the firm, thus providing added value of unquestionable importance (Viedma Marti 2001; Bontis 1998). Consequently, the lack of adequate human capital may have a negative effect on other activities that create value for the firm (Edvinsson and Malone 1997). The very nature of new ventures means that a fundamental part of this human capital lies with the entrepreneur or within the entrepreneurial team. Studies on the important role that human capital plays towards securing team success has focused on aspects such as: the level of knowledge, social competences, motivation or commitment of the team members (Vyakarnam and Handelberg 2005). In the following we presented different components of entrepreneur's human capital and how it can influence the decision to create the company by their own based on the rational process model.

Entrepreneur's previous knowledge. The entrepreneur's knowledge plays a key role in the first years of company life. To this end, knowledge acquired through professional activities carried out prior to creating the company is the most used indicator for measuring this asset 
(Stuart and Abetti 1990; Storey 1994; Bosma et al. 2004; Rauch et al. 2005). Miller et al. (1999) believe that related experience is the most useful indicator for measuring both human and intellectual capital. The experience of the entrepreneur has been considered one of the most important sources of knowledge and a determining factor in the success and growth of newly-created ventures (Basu and Goswami 1999).

Level and engagement in formal education represents another source of knowledge acquisition that has received attention in the literature surrounding entrepreneurship. Some argue that level of education is the basis for intellectual development, supporting the company enormously, providing the entrepreneur with higher levels of self-confidence in establishing a relationship with stakeholders or financing entities (Vesper 1990; Brüderl et al. 1992; Storey 1994; Van Praag and Cramer 2001; Watson et al. 2003).

Thus in completing a higher level of education and acquiring a certain degree of experience in the sector it is more likely that the potential entrepreneur will perceive themselves as possessing the necessary skills and competences for initiating and running a business.

Based on this assumption we present the following hypothesis:

H1 The entrepreneur's knowledge is positively related to entrepreneurial lone decision Hla_ The higher entrepreneur's experience the higher probability to create the company alone

HIb_ The higher entrepreneur's level of education the higher probability to create the company alone

Entrepreneur's social competences. These can be deemed intangible assets that are not intellectual or "right-brain" oriented and as such often tend to be neglected even though they may be equally as important to the organisation's future: we are referring to social 
competences (Andriessen 2004). Social skills do appear to be important for entrepreneurial success, as they are generally necessary for an entrepreneur to convince others to invest in or buy a product or service (Decker et al. 2012; Baron and Markman 2003; Zhao and Seibert 2006). Two of these social competences, namely social perception and adaptation, have received empirical support in so far as the value they contribute to the firm in the initial stage of its life support the achievement of higher revenues and profits in the future (Baron and Markman 2003).

It is these social capacities that permit the entrepreneur to interact with and engage in the cultivation of relationships with those with whom they are unfamiliar, and so display an aptitude for social adaptability as well as the ability to perceive the characteristics, intentions and motives of the other person (Baron and Markman 2003). A high level of competency is key for establishing core business relationships and vital for conducting effective negotiations with stakeholders. Baron and Markman (2003) found that entrepreneurs' social adaptability and accuracy in perceiving others was positively related to financial success.

Entrepreneurs may not initially possess the knowledge and competences that can lead to new venture success (Chandler and Lyon 2009). Potential entrepreneurs understand that personal networks can provide them with key resources in the form of information about the market, new opportunities, problem solving and/or even access to financial resources (Hoang and Antoncic 2003; Nicolaou and Birley 2003; Shane and Stuart 2002; Walter et al. 2006). Some authors assume that social relationships are established through seeking any type of complementarity (Smith and Ruiz 2007). Based on the rational approach that indicates that individuals look for complementarity of competencies when forming a group, those potential 
entrepreneurs with a higher degree of social competencies, will have the feeling of selfefficacy of make one important task for entrepreneur, which is networking (Birley 1984). Based on this assumption we present the following hypothesis:

H2_The entrepreneur's social competences are positively related to his entrepreneurial lone decision

H2a_The higher entrepreneur's social adaptability the higher probability to create the company alone

H2b_ The higher entrepreneur's social perception the higher probability to create the company alone

Entrepreneur's extrinsic motivation. The motive that drives the founder to develop his business project can either produce added value for the firm or have a negative effect on it. Various authors have studied the influence of entrepreneurs' motivations on the subsequent organisational processes (Gatewood et al. 1995; Van Praag 2003; Van Praag and Cramer 2001; Peña 2002; Collins-Dodd et al. 2004). Most of the aforementioned draw the conclusion that the owner most successful are driven by intrinsic motivation. This could take the form of: the transformation from innovatory idea to practical solution, or by the need to be his/her own boss, feeling that they are more likely to create a business that will have greater chances of personal success as opposed to embarking on what they perceive as the far more difficult task of finding a job. On the other hand, we find the extrinsic motivation, we meant individuals that are pushed into entrepreneurship by negative external forces, such as job dissatisfaction, difficulty finding employment, insufficient salary, or inflexible work schedule (Gilad and Levine 1986). 
Previous studies have demonstrated that unemployment has a detrimental influence on the self-efficacy (Aviram 2006; Zenger et al. 2013). Creating a company with a very high extrinsic motivation related with the impossibility to find a job can imply a lower perception of self-efficacy and can serve to motivate the future entrepreneur to acquire support in an effort to share the uncertainty of the entrepreneurial project.

Based on this assumption we present the last of the hypothesis:

H3_ The higher the entrepreneur's extrinsic motivation, the lower the probability to create the company alone

In the following Figure 1 all the hypothesis are summarized:

Figure 1. Relationship between entrepreneur's human capital and the propensity to create the company alone

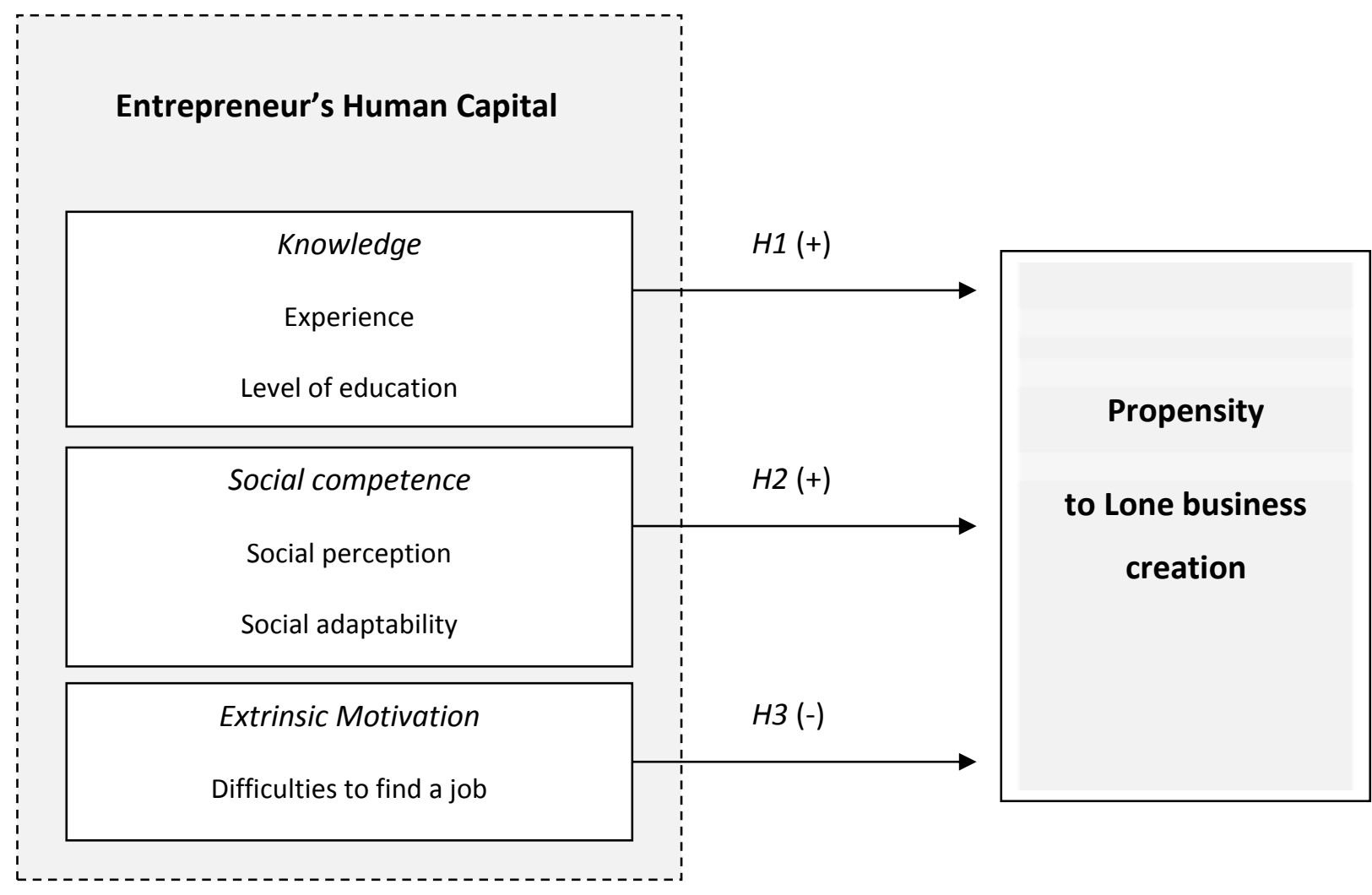

Source: own elaboration. 


\section{Methodology}

Characteristics of the sample

In order to verify the hypotheses that related the entrepreneur's human capital to the decision towards initiating a team project, we collated primary data by means of a questionnaire. For eligible inclusion in the study, the firm in question must have been undertaking a new activity, that is, a company that has simply changed its legal form or ownership has not been included in the population of this study. The final sample consist of: (1) 45 lone entrepreneurs; (2) 44 teams of two entrepreneurs and (3) 41 teams of more than two entrepreneurs. The questionnaires were all completed by the company owner who, in addition, participated actively in the daily activity of the firm and was, preferably, the person with overall responsibility. If after the first contact the questionnaire was found to have been completed by one of the firm's employees, it was immediately discarded. Furthermore, all the firms were funded in Spain and have between 3 and 42 months.

Variables

\section{Dependent variable}

The dependent variable was based on the decision to start a company alone or as a consortium (two or more partners). The variable was measured as a dicotomic variable coded 0 if the company was created by a lone entrepreneur and 1 if the company was initiated by an entrepreneurial group. To distinguish between both categories we established a definition in respect to the term entrepreneurial group. Thus, a company was considered an entrepreneurial group venture when two or more people were involved in the creation of the company and reflected both of the following characteristics: (1) had invested any money in company 
capital, (2) was involved in the day to day activity of the company, either in a part-time or full-time capacity.

Moreover the possible differences in group decisions were analysed, (with two people $(\mathrm{N}=$ 44) and more than two people $(\mathrm{N}=41))$. However the two groups were homogeneous regarding the factors under analysis and no perceptible differences were found in the variables.

\section{Independent variables}

Entrepreneur's previous knowledge: The entrepreneur's experience was measured using number of years' experience in the sector as the indicator (Sandberg and Hofer 1987; Duchesneau and Gartner 1990; Chandler and Jansen 1992; Van Praag 2003). In order to measure knowledge levels, we ascertained the level of study that had been acquired through formal education (e.g., compulsory studies, university studies, etc.). It was used a classification of seven items with all the possible level of studies, from primary education until postgraduate studies (Van Praag and Cramer 2001; Collins-Dodd et al. 2004). The respondents were asked to mark the highest level of education attained. All the entrepreneurs completed primary and secondary level studies and so these categories were joined. Thus, the final three categories of this variable are: undergraduate education, university education, post graduate education.

Entrepreneur's social competence. This variable was measured following the research of Baron and Markman (2003) who confirmed validity of the scale. Because of issues surrounding lack of precision and possible deviations with regard to self-reporting, Baron and Markman interviewed those close to the entrepreneurs in connection with the social competences of their associate. The findings confirmed that self-reporting was, on the whole, 
accurate when measuring the self-evaluation and reviews of entrepreneurs, against the responses provided by others. Thus we used a total of six items to assess the social perception and adaptability of the entrepreneur. The measurements of social perception captures issues like the level of the individual's ability to know how others feel in certain situations, when is the right time to ask someone a favour or the capacity to sufficiently know a person after conversing once or twice. With respect to social adaptability, the proposed items are related to the degree of sensitivity and understanding of the respondent and their capacity to communicate with strangers and talk to them on a range of issues.

Entrepreneur extrinsic motivation: Extrinsic motivation leading to company creation was studied by proposing options that the entrepreneur had to evaluate on a 7-point Likert scale according to the level of agreement with the following: "I created my company basically because I was not able to find a job" (Roberts 1989; Gimeno et al. 1997; Watson et al. 1998; Peña 2002). Because of the entrepreneur's could feel that they have different motivation, this variable was measured as a scale. A range of responses were proposed with the entrepreneurs identifying and marking the grade that best corresponded to their perceptions.

\section{Control variables}

Finally, we analysed a series of control variables that could impact on the dependent variable and have an overall effect on the final results. These variables were: (i) the first company created by the entrepreneur (ii) the age of the entrepreneurs, and finally, (iii) the gender of the entrepreneur.

The majority of these variables present significant differences between those who approach a new enterprise as a group and those working (see Table 1). For example, a greater proportion of males had decided to create the company on their own. Differences were also significant 
when we compare the level of experience, extrinsic motivation and social perception of both groups. No significant difference was evident between both groups with regard to age distribution or level of education.

Table 1. Comparison between entrepreneurial group decisions

\begin{tabular}{|c|c|c|c|}
\hline & $\begin{array}{c}\text { Individual decision } \\
(\mathrm{N}=45)\end{array}$ & $\begin{array}{c}\text { Group decision } \\
(\mathbf{N}=\mathbf{8 5})\end{array}$ & $\begin{array}{c}\mathbf{X}^{2} / \mathbf{t} \\
\text { (p-value) }\end{array}$ \\
\hline EXPERIENCE & 4.311 & 3.023 & $\begin{array}{l}-3.277 \\
(0.001)\end{array}$ \\
\hline $\begin{array}{l}\text { EDUCATION } \\
\text { No university education } \\
\text { University education } \\
\text { Postgraduate univ. education }\end{array}$ & $\begin{array}{l}37.3 \% \\
25.5 \% \\
46.7 \% \\
\end{array}$ & $\begin{array}{l}62.7 \% \\
74.5 \% \\
53.3 \% \\
\end{array}$ & $\begin{array}{l}2.897 \\
(.235)\end{array}$ \\
\hline EXTRINS. MOTIVATION & 1.444 & 2.741 & $\begin{array}{l}-3.478 \\
(0.001)\end{array}$ \\
\hline $\begin{array}{l}\text { SOCIAL PERCEPTION + } \\
\text { SOCIAL ADAPTABILITY + }\end{array}$ & $\begin{array}{l}-.3130 \\
-.0450 \\
\end{array}$ & $\begin{array}{r}.1021 \\
-.0238\end{array}$ & $\begin{array}{c}2.257 \\
(.026) \\
.372 \\
(.710) \\
\end{array}$ \\
\hline $\begin{array}{l}\text { PREVIOUS COMPANY } \\
\text { Yes } \\
\text { No }\end{array}$ & $\begin{array}{l}36.6 \% \\
33.7 \%\end{array}$ & $\begin{array}{l}63.4 \% \\
66.3 \%\end{array}$ & $\begin{array}{c}.101 \\
(0.751)\end{array}$ \\
\hline $\begin{array}{l}\text { GENDER } \\
\text { Male } \\
\text { Female }\end{array}$ & $\begin{array}{l}39.0 \% \\
16.0 \%\end{array}$ & $\begin{array}{l}61.0 \% \\
84.0 \%\end{array}$ & $\begin{array}{c}4.739 \\
(0.029)\end{array}$ \\
\hline AGE (In months) & 39.000 & 38.50 & $\begin{array}{l}-0.305 \\
(0.761)\end{array}$ \\
\hline
\end{tabular}

Notes: With the continuous variables we made t-test for the significance of the difference between the means of two independent samples. The rest of the differences are indicated using chi-square tests. Sample observations are not weighted.

+ Variables extracted from the factor analysis

\section{Results}

Before analysing the relations between the variables, we first examined the reliability of the scale used to measure the entrepreneur's social competence. For this we used Cronbach's alpha coefficient for determining the internal consistency of a scale, analysing the mean correlation of a variable with all the other variables from which the scale was built. Thus, we see that the scales show an acceptable level of consistency, with values upper that 0.7 . 
Table 2. Analysis of the reliability of the entrepreneur's social ability

\begin{tabular}{lccc}
\hline \multicolumn{1}{c}{ Variables } & $\begin{array}{c}\text { Reliability } \\
\text { (Cronbach's Alpha) }\end{array}$ & Mean & Standard Deviation \\
\hline Social perception & 0.719 & 5.11 & 1.69 \\
Social adaptation & 0.712 & 5.96 & 1.14 \\
\hline
\end{tabular}

Table 3 shows the inter-factor correlation matrix used to evaluate the significance level of the existing relationships. There are significant and positive correlations between the entrepreneur's experience and being male and the age, and negative relationship with the extrinsic motivation. Moreover, there is a positive correlation between having a previous company, the entrepreneur's age and being a male, and between age and gender. A series of tests revealed the non-presence of multicollinearity and in table 3 we can see that none of the correlations are superior to 0.4 .

Table 3. Correlation matrix

\begin{tabular}{|c|c|c|c|c|c|c|c|c|c|}
\hline & & 1 & 2 & 3 & 4 & 5 & 6 & 7 & 8 \\
\hline 1 & EXPERIENCE & 1.000 & & & & & & & \\
\hline 2 & EDUCATION & -.069 & 1.000 & & & & & & \\
\hline 3 & $\begin{array}{l}\text { EXTRINSIC } \\
\text { MOTIVAT }\end{array}$ & $-.224 *$ & .053 & 1.000 & & & & & \\
\hline 4 & SOCIAL PERCEP & .124 & .133 & .105 & 1.000 & & & & \\
\hline 5 & SOCIAL ADAPTAB & -.013 & $.179 *$ & -.043 & -.011 & 1.000 & & & \\
\hline 6 & $\begin{array}{l}\text { PREVIOUS } \\
\text { COMPANY }\end{array}$ & .138 & -.103 & -.129 & -.028 & .118 & 1.000 & & \\
\hline 7 & GENDER & $.219 *$ & -.141 & $-.211 *$ & .077 & .021 & $.257 * *$ & 1.000 & \\
\hline 8 & AGE & $.323 * *$ & -.025 & -.115 & -.051 & -.052 & $.315^{* *}$ & $.247 * *$ & 1.000 \\
\hline
\end{tabular}

Notes: Spearman rank correlation (1-tailed significance); ** Correlation is significant at the 0.01 level (1-tailed), * significant at the 0.05 level (1-tailed). Sample observations are not weighted.

Because the dependent variables were binary choice variables, logistic regressions were used to test the hypotheses. Reference cell coding was applied to the categorical variables as follows: (i) for the education variable, non-university study was used as the reference group; (ii) for previous company, not having a previous company served as the reference group; and (iii) for gender, female was the reference. 
A potential limitation to logit analysis is multicollinearity, which can occur when there is strong linear dependence among the independent variables (Hosmer and Lemeshow 2000). Multicollinearity is manifested by extraordinarily large estimated standard errors (and sometimes by large estimated coefficients), which can result in a lack of statistical significance of independent variables, even though the overall model can be strongly significant. As shown in Table 3, the model coefficients and standard errors in the present data were not extraordinary large, which suggests that multicollinearity was not a problem in this case.

Table 4 shows the results of the goodness of fit of the models (using the likelihood ratio test, Pearson chi-square, and the Hosmer-Lemeshow test) and test of variance using the Nagelkerke-statistic (pseudo $\mathrm{R}^{2}$ ). The Pearson chi-square tests demonstrated that the models were globally significant, and the p-value of the Hosmer and Lemeshow tests (greater than the significance level of 5\%) indicated that the models fitted quite well.

To test Hypotheses, the model presented in table 4 logistic regressions were undertaken, with 'THE DECISION TO INITIATE THE COMPANY AS A GROUP OR AS AN INDIVIDUAL' as the dependent variable and entrepreneur's 'KNOWLEDGE', 'EXTRINSIC MOTIVATION' 'SOCIAL COMPETENCES' as the independent variables, and the variables 'AGE', 'GENDER', and 'PREVIOUS COMPANIES as control variables.

Table 4 shows the results of testing the hypotheses. In the sample analysed, if the entrepreneur had previous experience in the sector significantly decreased the likelihood of deciding to create the company with other people. In other words, if an individual has knowledge within the sector, their preferred choice is to start a company on their own. 
Table 4. Results of logistic regression for individual vs groups decision to create the company

\begin{tabular}{|c|c|c|c|c|}
\hline & B & Std. Err. & Sig. & OR \\
\hline EXPERIENCE & -.327 & .114 & $.004 * *$ & .721 \\
\hline \multicolumn{5}{|l|}{ EDUCATION } \\
\hline No university education & & & 309 & \\
\hline University education & .801 & 697 & 250 & 2.228 \\
\hline Postgraduate univ. education & 1.181 & .770 & .125 & 3.258 \\
\hline EXTRINS. MOTIVATION & .327 & .151 & $.026^{*}$ & .721 \\
\hline$\overline{\text { SOCIAL PERCEPTION }}$ & .575 & .234 & $.014 *$ & 1.776 \\
\hline SOCIAL ADAPTABILITY & .121 & .228 & .595 & 1.129 \\
\hline \multicolumn{5}{|l|}{$\overline{\text { PREVIOUS COMPANY }}$} \\
\hline Yes & -.428 & .518 & .408 & .652 \\
\hline \multicolumn{5}{|l|}{ GENDER } \\
\hline Male & .825 & 660 & 211 & 2.282 \\
\hline$\overline{\mathbf{A G E}}$ & .025 & .030 & .391 & 1.026 \\
\hline Constant & -.369 & 1.335 & .782 & .692 \\
\hline $\mathrm{N}$ & \multicolumn{4}{|c|}{130} \\
\hline Hosmer and Lemeshow test & \multicolumn{4}{|c|}{$6.947(0.542)$} \\
\hline Chi Square & \multicolumn{4}{|c|}{$32.651(0.000)$} \\
\hline Pseudo $R^{2}$ (Nagelkerke) & \multicolumn{4}{|c|}{0.319} \\
\hline-2 Log likelihood & \multicolumn{4}{|c|}{126.935} \\
\hline Percentage predicted correctly & \multicolumn{4}{|c|}{77.6} \\
\hline
\end{tabular}

However, there is not a significant relationship between the level of study attained and the decision to engage in entrepreneurial activity as a group. Hypothesis H1 was thus partially supported. It would seem that knowledge acquired through previous experience (H1a), as opposed to knowledge acquired through education (H1b), has a greater impact on deciding whether or not to pursue a collaborative new venture.

These results confirm the significance of the role played by experience in the first years of company life. In this case, this experience can have a direct impact on the entrepreneur's perception of their own capacity. Thus the previous experience in the same sector can make the entrepreneur to know the future customers, market opportunities and resource needs. This fact can positively influence self-confidence and therefore indicates this group of entrepreneurs are more prone to lone company creation. Regarding level of education, the 
results are inconclusive regarding having a direct impact in the very early stage of company life. Thus, despite level of formal education, the potential entrepreneur does not feel so ready or confident to address a new and uncertain endeavour.

Regarding hypothesis 2, we can find significant differences in the entrepreneur's social perception (H2b) between two groups but not in the social adaptability (H2a). Thus social competences only partially affect the probability of creating a company as a group venture. The entrepreneurs that decide to collaborate in order to create a company have a higher social perception and have the ability to perceive the most appropriate opportunity to talk with someone or to elicit goodwill. These results are contrary to the theoretical arguments for supporting hypothesis 2 . Thus the results do not support that a positive self-evaluation and confidence relating to their effectiveness for the possibility of obtaining the resources they require from contacts and different networks make that the entrepreneur prefer to create the company alone, but it creates the opposite effect. In the following section, these results are discussed according to the literature.

These differences were not observed in the entrepreneur's social adaptability measurement, understood by the entrepreneur's capacity to adapt to new situation and people. The ability to be with new people in new situations can favour a tendency to work as part of a team and feel comfortable in this situation, explaining why a negative effect was not found in the decision to create an entrepreneurial team. This social competence can be hiding an internal preference to work in team. Thus hypothesis two is only partially accepted.

Finally, table 3 shows the empirical support for hypothesis 3 . The results demonstrate that for this sample the entrepreneurs who decided to create a company with at least one other person is more likely to be extrinsically motivated towards creating a business. 


\section{Discussion of the results and conclusions}

In the field of entrepreneurship it is very common to forget alternative theoretical frameworks when the results are not as one would have expected (Zahra 2007). The application of some theories often lack rigor and creativity, producing obvious or inconclusive results. For this reason it is very important to discuss the results critical analyzing the assumption of the theory in order to understand how other theoretical approaches can help to understand the phenomenon understudy (Zahra 2007). Johannisson et al. (2007) emphasized the value of analyzing a unique phenomenon from different theoretical perspectives. This exercise permits a depth of exploration of a phenomenon that supports the academic community to understand application and impact.

In this case, the theory of rational approach does not support the results of the second hypothesis that argued that the entrepreneur's social competences are positively related to his entrepreneurial lone decision. To this end, we utilise an alternative theoretical approach that attempts to explain the reason for group formation from a social psychological approach. This approach emphasises the interpersonal fit between team members and the need for a smoothly functioning group process (Forbes et al., 2006; Aldrich and Kim, 2007). Indeed, motivation for social contact is a central influence on human behaviour (Baumeister \& Leary, 1995; Hill, 1987). The results of our study reflect that individuals with higher social perception prefer to form a company adopting a group approach. These individuals have the ability to know how others feel in certain situations or they believe they have the capacity to sufficiently know a person after conversing once or twice. This demonstrates the reflective approach of someone aware of the importance of the social contacts and of all the benefits that this involves. Decker et al. (2012) found a positive association between entrepreneurial careers and the need for 
positive stimulation from other persons. Therefore, persons with entrepreneurial interests enjoy interacting with other people, but are not, it would appear, emotionally dependent upon them.

Moreover, the entrepreneurs' skills of understanding others and empathic recognition can indicate an understanding of the benefits of collaborate working brings and reduces the negative perceived effects towards that of building a team. Thus social competences have been demonstrated to be important for making an entrepreneurial group more likely to experience success (Ensley et al. 2002). These individuals can be looking for more a social regards that the rational process model can not explained, we meant positive affect, attention or reduction of negative affect through social contact.

On the other hand, sector experiences instil confidence and support the capacity to pursue company creation as a lone project. Those possessing greater sector experience have had time to learn about demand, customers, the innovative process and the environmental factors that influence his business activity. Entrepreneurship literature has extensively demonstrated the importance of the entrepreneur's prior experience, particularly sector experience, towards succeeding in a new venture (Brüderl et al. 1992; Lerner and Almor 2002; Van Praag 2003; Bosma et al. 2004). This experience supports key skills and core knowledge development, particularly in regard to: securing access to required resources through networks, understanding and analysing customer preferences or systems of production. Moreover, experience can support a perception of confidence and decrease the uncertainty of the first years in a new venture. To this end, different authors adopting a psychological approach have suggested that knowledge reduces feelings of uncertainty. This notion may be applied to the uncertainty and risk surrounding entrepreneurial activity (Janney and Dess 2006). 
Regarding motivation, the external pressure of, for instance, being unemployed and unable to find a job can influence an entrepreneur's self-perception and competency in different ways. On the one hand being unsuccessful at gaining employment has a negative impact on confidence levels, makes them less secure in their own ability to pursue business start-up in a lone capacity. The need for support and the notion that they don't possess certain competencies that others could provide increases the likelihood of collaborative company creation. On the other hand, they face a higher level of uncertainty, are less confident is their ability to achieve positive outcomes and are initially, less confident in the likelihood of securing an income from the business. A higher level of pressure is experienced in combatting the negativity and securing an income. This battle with self-confidence and the necessity to achieve an income makes it more likely to seek out others to work with in order to increase the probability of success and to share the uncertainty of the first years' of company life.

This study has investigated the differences between lone and group entrepreneurs in regard to human capital thereby contributing to how and why the different paths are pursued. The main conclusions of the empirical analysis demonstrate that certain entrepreneur's human capital variables (previous experience, social competence and extrinsic motivation) are related to the decision to create a company as a lone venture or collaboratively as part of a group.

The results of this research have several implications. From an academic point of view contribute to the knowledge of the entrepreneurial team formation phenomenon. The research of this topic is still scares if we compare with the research focus on individual entrepreneur. To understand why entrepreneurs decide to act as a team can helps consultants and institutions when they try to create teams ad hoc to exploit business opportunities. 
Although the findings of this study are significant, some limitations are acknowledged. The sample is comprised by 85 entrepreneurial teams and 45 lone entrepreneurs. A larger and more diverse sample will help to enrich the results. Moreover, future researches could include teams from different countries and cultures, to compare the cultural values in the propensity to work individually or in team. This study has been pioneering in identifying individual human factors that can influence the higher propensity to create a company alone or as a group however the results that not goes deeper to other factors that can be influencing this decision like the entrepreneur's environment or his perception about teamwork. Moreover, this study lays the foundations upon which further research on the important role that entrepreneurs' characteristics and background can play in entrepreneurship and the impact it has on the decision making process: lone enterprise or group venture?

Future research could extend the study's approach to the investigation of self- efficacy, using it for measuring the possible mediating effect between human capital variables and the entrepreneurial group decision. Also, while the objective of this study is to measure the lone propensity decision, it would be of interest to investigate the performance as the last dependent variable in the model.

\section{References}

Aldrich, Howard E., and Philip H. Kim. 2007. "Small worlds, infinite possibilities? How social networks affect entrepreneurial team formation and search." Strategic Entrepreneurship Journal 1: $147-165$.

Andriessen, Daniel. 2004. "IC valuation and measurement: classifying the state of the art." Journal of Intellectual Capital 5: 230-242.

Aviram, Arie. 2006. "A study of factors that influence unemployed persons." Journal of Employment Counseling 43: 154-167. 
Baron, Robert A., and Gideon D. Markman 2003. "Beyond social capital: the role of entrepreneurs social competence in their financial success." Journal of Business Venturing 18: 41-60.

Basu, Anuradha, and Arati Goswami. 1999. "Determinants of South Asian entrepreneurial growth in Britain: a multivariate analysis." Small Business Economics 13: 57-70.

Baumeister, Roy F., and Mark R. Leary. 1995. "The need to belong: Desire for interpersonal attachments as a fundamental human motivation." Psychological Bulletin 117: 497-529.

Becker, Brian E., Mark A. Huselid, and David Ulrich. 2001. The HR scorecard: linking people, strategy, and performance. Boston: Harvard Business School Press.

Ben-Hafaiedh-Dridi, Cyrine. 2010. "Entrepreneurial team formation: Any rationality?" Frontiers of Entrepreneurship Research 30: Article 1. http://digitalknowledge.babson.edu/fer/vol30/iss10/1

Birley, Sue. 1984. "Finding the new firm." Proceedings of the Academy of Management Meetings 47: 64-68.

Bontis, Nick. 1998. "Intellectual capital: and exploratory study that develops measures and models." Management Decision 36: 63-76.

Bontis, Nick. 2002. National intellectual capital index: Intellectual capital development in the Arab Region. Ontario: Institute for Intellectual Capital Research.

Bosma, Niels, Mirjam Van Praag, M., Roy Thurik, and G. Ardine DeWit. 2004. "The value of human and social capital investments for the business performance of start-ups." Small Business Economics 23: 227-236.

Boyd, Nancy G., and George S. Vozikis. 1994. "The influence of self-efficacy on the development of entrepreneurial intentions and actions." Entrepreneurship Theory and Practice 18: 63-77.

Brüderl, Josef, Peter Preisendörfer, and Rolf Ziegler. 1992. "Survival chances of newly funded business organizations." American Sociological Review 57: 227-242.

Burn, Shawn M. 2004. Groups. Theory and practice. California: Thonson and Wadsworth.

Cartwright, Dorwin, and Alvin Zander. 1968. Group dynamics: Research and theories. New York: Harper and Row.

Chandler, Gaylen N., and Erik Jansen. 1992. "The founder's self-assessed competence and venture performance." Journal of Business Venturing 7: 223-236.

Chandler, Gaylen N., and Douglas W. Lyon. 2009. "Involvement in knowledge-acquisition activities by venture team members and venture performance." Entrepreneurship Theory and Practice 33: $571-592$

Chowdhury, Sanjib. 2005. "Demographic diversity for building an effective entrepreneurial team: is it important?" Journal of Business Venturing 20: 727-746. 
Collins-Dodd, Colleen, Irene M. Gordon, and Carolyne Smart. 2004. "Further evidence on the role of gender in financial performance." Journal of Small Business Management 42: 395-417.

Cooney, Thomas. 2005. "What is an entrepreneurial team?" International Small Business Journal 23: 226-235.

Decker, Wayne H., Thomas J. Calo, and Christy H. Weer. 2012. "Affiliation motivation and interest in entrepreneurial careers.” Journal of Managerial Psychology 27: 302-320.

Duchesneau, Donald A., and William B. Gartner. 1990. "A profile of new venture success and failure in an emerging industry." Journal of Business Venturing 5: 297-312.

Edvinsson, Leif, and Michael Malone 1997. Intellectual capital: realising your company's true value by finding its hidden brainpower. New York: Harper Collins.

Eisenhart, Katheleen M., and Claudia Bird Schoonhoven. 1990. "Organizational growth: Linking founding team, strategy, environment, and growth among U.S. semiconductor ventures." Administrative Science Quarterly 35: 504-529.

Ensley, Michael D., Allison W. Pearson, and Allen C. Amason. 2002. "Understanding the dynamics of new venture top management teams: cohesion, conflict, and new venture performance." Journal of Business Venturing 17: 365-386.

Forbes, Daniel P., P.S. Borchert, M.E. Zellmer-Bruhn, and H.J. Sapienza. (2006). "Entrepreneurial Team Formation: An Exploration of New Member Addition.” Entrepreneurship Theory and Practice 30: 225-248.

Frances, Deborah H., and William R. Sandberg. 2000. "Friendship within entrepreneurial teams and its association with team and venture performance." Entrepreneurship Theory and Practice 25: $5-26$.

Friar, John H., and March H. Meyer. 2003. "Entrepreneurship and start-ups in the Boston region: factors differentiating high-growth ventures from micro-ventures." Small Business Economics 21: $145-152$.

Gatewood, Elizabeth J., Kelly G. Shaver, and Willam B. Gartner (1995). "A longitudinal study of cognitive factors influencing start-up behaviours and success at venture creation." Journal of Business Venturing 10: 371-391.

Gilad, Benjamin, and Philip Levine. 1986. "A Behavioral model of entrepreneurial supply.” Journal of Small Business Management 24: 45-54.

Gimeno, Javier, T. Folta, A. Cooper, and C. Woo. 1997. "Survival of the fittest? Entrepreneurial human capital and the persistence of underperforming firms.” Administrative Science Quarterly 42: 750-783. 
Hambrick, Donald C., Theresa Seung Cho, and Ming-Jer Chen. 1996. "The influence of top management team heterogeneity on firms' competitive moves." Administrative Science Quarterly 41: 659-684.

Hill, Craig A. (1987). "Affiliation motivation: People who need people... but in different ways." Journal of Personality and Social Psychology 52: 1008-1018.

Higashide, Hironori, and Sue Birley. 2002. "The consequences of conflict between the venture capitalist and the entrepreneurial team in the United Kingdom from the perspective of the venture capitalist." Journal of Business Venturing 17: 59-78.

Hoang, Ha, and Bostjan Antoncic. 2003. "Network-based research in entrepreneurship: a critical review." Journal of Business Venturing 18: 165-187.

Hosmer, David W., and Stanley Lemeshow. 2000. Applied Logistic Regression. New York: John Wiley \& Sons, Inc.

Huici, Carmen, F. Molero, A. Gómez, and J.F. Morales. 2011. Psicología de los Grupos. Madrid: UNED.

Janney, Jay J., and Gregory Dess. 2006. "The risk concept for entrepreneurs reconsidered: New challenges to the conventional wisdom." Journal of Business Venturing 21: 385-400.

Johannisson, Bengt, L. Centeno Caffarena, A. Discua Cruz, E. Hormiga Pérez, M. Kapelko, K. Murdock, D. Nanka-Bruce, M. Olejarova, A. Sánchez López, A. Sekki, C. Stoian, H. Tötterman, and A. Bisignano. 2007. "Interstanding the industrial district: Contrasting Conceptual Images as a Road to Insight." Entrepreneurship and Regional Development 19: 527554.

Johanson, Ulf. 2005. "A human resource perspective on intellectual capital." In Perspective on intellectual capital. Multidisciplinary insights into management, measurement and reporting, edited by B. Marr, 96-105. Boston: Elsevier.

Kamm, J.B., and A.J. Nurick. 1993. "The stages of team venture formation: A decision-making model." Entrepreneurship Theory and Practice 17: 17-27.

Kamm, Judith B., J.C. Shuman, J.A. Seeger, and A.J. Nurick. 1990. "Entrepreneurial teams in new venture creation: a research agenda." Entrepreneurship Theory and Practice 14: 7-17.

Lechler, Thomas. 2001. "Social interaction: a determinant of entrepreneurial team venture success." Small Business Economics 16: 263-278.

Lerner, Miri, and Tamar Almor. 2002. "Relationships among strategic capabilities and the performance of women-owned small ventures." Journal of Small Business Management 40: 109-125. 
Marr, Bernard, and Göran Roos. 2005. "A strategy perspective on intellectual capital.” In Perspective on intellectual capital. Multidisciplinary insights into management, measurement and reporting, edited by B. Marr, 28-41. Boston: Elsevier.

Miller, Marilyn, B.D. DuPont, V. Fera, R. Jeffrey, B. Mahon, B.M. Payer, and A. Starr. 1999. "Measuring and reporting intellectual capital from a diverse Canadian industry perspective." Paper presented at the International Symposium Measuring Reporting Intellectual Capital: Experiences, Issues, and Prospects, OECD, Amsterdam, June 9-11.

Molleman, Eric, and Jannes Slomp. 2006. "The impact of team and work characteristics on team functioning." Human Factors and Ergonomics in Manufacturing \& Service Industries 12: 1-15.

Nicolaou, Nicos, and Sue Birley. 2003. "Social networks in organizational emergence: the university spinout phenomenon." Management Science 49: 1702-1725.

Peña, Iñaki. 2002. "Intellectual capital and business start-up success." Journal of Intellectual Capital 3: $180-198$.

Rafferty, James, and Jane Tapsel. 2001. "Self-managed work teams and manufacturing strategies: Cultural influences in the search for team effectiveness and competitive advantage." Human Factors and Ergonomics in Manufacturing \& Service Industries 11: 19-34.

Rauch, Andreas, Michael Frese, and Andreas Utsch. 2005. "Effects of human capital and long-term human resources development and utilization on employment growth of small-scale business: A causal analysis." Entrepreneurship Theory and Practice 29: 681-698.

Ribeiro-Soriano, Domingo, and David Urbano. 2009. "Overview of collaborative entrepreneurship: An integrated approach between business decisions and negotiations." Group Decision and Negotiation 18: 419-430.

Roberts, Edward. 1989. "The personality and motivations of technological entrepreneurs." Journal of Engineering and Technology Management 1: 1-19.

Roberts, Edward. 1991. Entrepreneurs in high-technology: Lessons from MIT and beyond. New York: Oxford University Press.

Roure, Juan B., and Modesto A. Maidique 1986. "Linking prefunding factors and high technology venture success: An exploratory study.” Journal of Business Venturing 1: 295-306.

Sandberg, William R., and Charles W. Hofer. 1987. "Improving new venture performance: the role of strategy, industry structure and entrepreneur." Journal of Business Venturing 2: 5-29.

Scherer, Robert F., J.S. Adams, S.S. Carley, and F.A. Wiebe. 1989. "Role model performance effects on development of entrepreneurial career preference." Entrepreneurship Theory and Practice 13: 53-71. 
Schjoedt, Leon, and Sascha Kraus. 2009. "Entrepreneurial teams: definition and performance factors." Management Research News 32: 513-524.

Segal, Gerry, Dan Borgia, and Jerry Schoenfeld. 2005. "The motivation to become an entrepreneur." International Journal of Entrepreneurial Behaviour \& Research 11: 42-57.

Shane, Scott A., and Toby Stuart. 2002. "Organizational endowments and the performance of university start-ups." Management Science 48: 154-170.

Smith, Jessi L., and John M. Ruiz. 2007. "Interpersonal orientation in context: Correlates and effects of interpersonal complementary on subjective and cardiovascular experiences." Journal of Personality 75: 679-708.

Storey, David J. 1994. Understanding the Small Business Sector. London-Boston: International Thomson Business Press.

Stuart, Robert W., and Pier A. Abetti. 1990. "Impact of entrepreneurial and management experience on early performance." Journal of Business Venturing 5: 151-162.

Sveiby, Karl Erik. 2000. La nueva riqueza de las empresas. Barcelona: Gestión 2000.

Tihula, Sanna, Jari Huovinen, and Matthias Fink. 2009. "Entrepreneurial teams vs management teams. Reasons for team formation in small firms." Management Research News 3: 555-566.

Timmons, Jeffry A. 1999. New Venture Creation: Entrepreneurship for the 21st century. Boston, MA: Irwin/McGraw Hill.

Ucbasaran, Deniz, A. Lockett, M. Wright, and P. Westhead. 2003. "Entrepreneurial founder teams: Factors associated with member entry and exit." Entrepreneurship Theory and Practice 28: $107-128$

Utterback, James, M. Meyer, E. Roberts, and G. Reitberger. 1988. "Technology and industrial innovations in Sweden: A study of technology-based firms formed between 1965 and 1980." Research Policy 17: 15-26.

Vanaelst, Iris, B. Clarysse, M. Wright, A. Lockett, N. Moray, and R. S'Jegers. 2006. "Entrepreneurial team development in academic spinouts: An examination of team heterogeneity." Entrepreneurship Theory and Practice 30: 249-271.

Van Praag, C. Mirjam. 2003. "Business survival and success of young small business owners." Small Business Economics 21: 1-17.

Van Praag, C. Mirjam, and Jan Salomon Cramer. 2001. "An estimated equilibrium model of business formation and labour demand by entrepreneurs." Economica 68: 45-62.

Vesper, Karl H. 1990. New Venture Strategies. New Jersey: Prentice-Hall, Englewood Cliffs.

Viedma Marti, José María. 2001. "ICBS - Intellectual Capital Benchmarking System.” Journal of Intellectual Capital 2: 148-165. 
Vyakarnam, Shailendra, and Jari Handelberg. 2005. "Four themes of the impact of management teams on organizational performance: Implications for future research of entrepreneurial teams." International Small Business Journal 23: 236-256.

Walter, Achim, M. Auer, and T. Ritter. 2006. "The impact of network capabilities and entrepreneurial orientation on university spin-off performance." Journal of Business Venturing 21: 541-567.

Watson, Kathryn, Sandra Hogarth-Scott, and Nicholas Wilson. 1998. "Small business start-ups: success factors and support implications." International Journal of Entrepreneurial Behaviour \& Research 4: 217-238.

Watson, Warren E., Louis D. Ponthieu, and Joseph W. Critelli. 1995. "Team interpersonal process effectiveness in venture partnerships and its connection to perceived success." Journal of Business Venturing 10: 393-411.

Watson, Warren, Wayne H. Stewart, and Anat BarNir. 2003. "The effects of human capital, organizational demography and interpersonal processes on venture partner perceptions of firm profit and growth." Journal of Business Venturing 18: 145-164.

West, G. Page. 2007. "Collective cognition: When entrepreneurial teams, not individuals, make decisions." Entrepreneurship Theory and Practice 31: 77-102.

Wood, Robert, and Albert Bandura. 1989. "Social cognitive theory of organizational management." The Academy of Management Review 14: 361-384.

Zahra, Shaker A. 2007. "Contextualizing theory building in entrepreneurship research." Journal of Business Venturing 22: 443-452.

Zenger, Markus, H. Berth, E. Brähler, and Y. Stöbel-Richter. 2013. "Health Complaints and Unemployment: The Role of Self-Efficacy in a Prospective Cohort Study." Journal of Social and Clinical Psychology 32: 97-115.

Zhao, Hao, and Scott E. Seibert. 2006. "The Big Five personality dimensions and entrepreneurial status: A meta-analytical review." Journal of Applied Psychology 91: 259-271.

Zhou, Wencang, Donald Vredenburgh, and Edward G. Rogoff. 2015. "Informational diversity and entrepreneurial team performance: moderating effect of shared leadership." International Entrepreneurship and Management Journal 11: 39-55.

This is an Open Access article distributed under the terms of the Creative Commons Attribution-Non-Commercial-No Derivatives License (http://creativecommons.org/licenses/by-nc-nd/4.0/), which permits non-comercial re-use and distribution, provided the original work is properly cited, and is not altered or transformed in any way. 